\title{
Computer-Based Applications for Quality Management Process in Shipbuilding
}

\author{
Renny Rahmadi Putra ${ }^{1}$, Triwilaswandio W.P ${ }^{1}$, and M. Sholikhan Arif ${ }^{1}$
}

\begin{abstract}
In a Shipyard, Quality Management has not been executed systematicaly. Management of inspections are not supported by system which can help Shipyard, Owner Surveyor, Class and State Regulator to control, to search, to review, to evaluate and to do the inspections. This research has a main goal to design a Computer-based Application that makes Quality Management process in Shipbuilding better. Firstly, the Existing Quality management in shipyard was observed which is taken as the sample is PT. PAL Indonesia Shipyard. Secondly, Determining parameters are required in Quality Management Application. Thirdly, Designing Computer-based Applications based on application parameters. Application parameters are identified during shipbuilding stages, processes, outfittings and ship documents, as well as standards and check lists. Software used to design the application is combination of $\mathrm{PHP}$ as programming language, Sublime Text 2 as text editor and MySQL as database. This computer-based applications can help quality management implementation in controlling, searching, reviewing, evaluating, and doing the inspection. Once the application has been designed, it was tested by verification and comparison systems. It is concluded that the application system is better than the existing system which is personally conducted in the Shipyard.
\end{abstract}

Keywords - Application, Inspection, Shipbuilding, Quality management.

\section{INTRODUCTION}

Ship Inspections were very important process that was done to avoid errors in Shipbuilding process, the errors can decrease the ship quality which was built by a shipyard. Each inspection will generate the inspection document. The inspection processes which were conducted by the Quality Control and Quality Assurance a shipyard, typically use check sheet, so that the inspection documents have the form of check sheets [1].

The Inspection Management was still done manually such as the inspection documents which form of sheets of papers and scan files. Papers were stored in the cupboard and scan files were separately saved in computer folders. The inspection documents do not support the implentation of Inspection Management for controlling, searching, reviewing, evaluating and doing the inspection. Inspection documents are huge numbers, that are very susceptible to lost. It takes an additional media that can assist the Inspection Management as well as the computer applications. It can process the Inspection documents centrally in one program and integrated with the others into the computer, so that can display additional information for users. If the Inspection Management does well, so the Shipyard quality management works well too, because the Inspection Management is a part of the implementation of quality management process.

\footnotetext{
${ }^{1}$ Renny Rahmadi Putra, Triwilaswandio W.P, and M. Sholikhan Arif are with Departement of Naval Architecture and Shipbuilding Engineering, Sepuluh Nopember Institute of Technology, Surabaya,
}

The development of computerized system would assist in the implementation of computer application for Shipyard quality management. Computer applications is able to provide some services, such as input, store, display, print, search, monitor and evaluate the inspection, so that the application would be more appropriate in terms of supporting ship quality improvement.

A. Quality Management

Quality management done based on the PDCA cycle (Plan - Do - Check - Action) is planning, execution, evaluation and corrective action on quality issues. The quality established by the company is a result of the Management process or commonly known as quality management [2].

\section{B. Shipbuilding Process}

Figure 1. shows the shipbuilding process that starts from defining Owner Requirement, designing ships, contract, and then ship production process. The production process is a collaboration of planning, scheduling and producing stages. The production process is a main process of Shipbuilding. The ship quality is influenced by the production process which is executed, monitored and checked by Shipyard. The ship production process is a multi-process executed in series. The production process includes the stage of components identification, fabrication, assembly, erection, outifitting, launching, commissioning, sea trials and delivery [3].

C. Quality and Standards in Shipbuilding

Quality control is done through inspection process, including testing to obtain an assurance that the ship includes all components of the machinery, electrical systems, equipment and all equipment which includes aspects of the quality of material, fabrication system, manufacturing system and installation components conform with technical specifications, ship classification rules, state regulations, and standards that have been approved by ship owner and shipyard. Inspection and testing are performed referring to the Contract, the Classification rule, Quality Standards of Shipyard [4], IACS Shipbuilding Standards [5], SOLAS and IMO regulations.

\section{Computer Applications}

Computer-based applications is a data processing system into a quality information[6]. The application integrates man and machine that utilizes hardware, software, procedures and databases for providing information to support the operation, management and decision-making in the company. Application is built by the programming language to input the instructions of applications, such as PHP programming language [7]. Application programming is supported by using a text editor software to formulate the programming language of application such as Sublime Text 2. And then, computer

60111,Indonesia,. $\quad$ E-mail: $\quad$ renny.rahmadi.p@gmail.com; triwilas.its@gmail.com; ichan_narch@yahoo.co.id. 
applications is also supported by other software which the application runs the data in that software as well as database software like MySQL database [7].

\section{E. Structure Data}

Somethings that must be considered in the designing of the application, is the type of data structure which is defined in the system or method for running the application. The data structure can be presented in the form of Database, Data Flow Diagram, Entity Relationship Diagram and Use Case Diagram. A database is a collection of all data that is stored in a single or multiple files. Data Flow Diagrams (DFD) is a diagram used to describe the processes that occur on the system. Use Case Diagram (UCD) is a text-based method for describing and documenting the process. Entity Relationship Diagram (ERD) is a diagram to show the information created, stored and used in the application [8]

\section{METHOD}

\section{A. Data Collecting}

Data Collecting was conducted through literature studies and field surveys. The datas include inspection documents during the shipbuilding process from component identification to delivery stage. The field survey was conducted in PT. PAL Indonesia Shipyard.

\section{B. Data Processing}

Data processing was performed by referring to the observation of existing conditions and data collecting process. In this stage, the data are classified based on the shipbuilding stages, process, ship components, standards and check lists. Data processing will generate application parameters which are identified during the shipbuilding stages, processes, components and ship documents, as well as standards and check lists.

\section{Designing Application}

Designing application was done through modelling applications, designing interface, designing database, and coding applications stage see Figure 2. Modeling applications are illustrated through use case diagram, data flow diagram and entity relationship diagram. Designing Interfaces are illustrated with designs mock-up application. Designing database applications use MySQL software. Coding application is the most important stage in the designing application, which use Sublime Text 2 as text editor and PHP as programming language.

\section{Validating Application}

Validation testing is done by offline and online, to ensure quality management applications that can be deployed and running well. Application has been made, is tested by comparisons system and verification through directly application usage and respondent-assessment questionnaire to the application.

\section{RESULTS AND DISCUSSION}

\section{A. Modeling Application}

Before modeling applications, the application parameters should be previously determined. The application parameters were identified during shipbuilding process, components and ship documents, as well as check lists and inspection standards. Modeling application easily communicate the intent and goals of application to the programmer or user. Modeling application is shown by applications mock up, data flow diagram, use case diagram and entity relationship diagram, see Figure 4., Figure 6. and Figure 7.

B. Designing Computer Applications

Application was developed based on framework in Figure 3. Application operates database system which stored a lot of data about Shipbuilding Inspection. Designing Application started from designing interface. Application interface was illustrated with mock up of applications such as Figure 4.. Designing Interface is necessary to facilitate the planning of any contents which are displayed in the application. The contents contain of application parameters. Computer application is an application that displays the information which has been stored in the database system. Database is built by using the MySQL software.

Once the interface and database of application has been designed, then the next stage is a coding system by inserting a programming language into the text editor. Computer applications is built by using Sublime Text 2 software as text editor, and PHP as programming language. Basically PHP is a web-based program, that can add functionality to applications that can be used online. C. Simulation of Quality Management Applications

This application involves 8 Users. Users are divided into two types, they are Internal Shipyard (QA, QC, Design, Procurement and Production Department) and External Shipyard (Classification Society, Owner Surveyor and State Regulators). Admin is the main user of the quality management application, admin has completely permissions in the application. Admin is divided into two types, they are QA Engineering as Main Admin and QC / QA as Field Admin. Admin has permission to input, to save, to edit, to add, to download, to delete, to view, to print data, to approve registrars, and to delete registrars. While the user only has permission to print, to download and to view data of inspections.

Figure 5., indicates that the application needed Internet networks, computers, and User / Admin to operate it. By using a browser, and By typing the address of quality management application in the url address, User / Admin will enter into the Quality management application. Users have to register previously and registered as users application.

Figure 6., The work flow of Admin to operate application. Admin can add project, approve applicants and see the project on the home page application. Application menu appears when Admin selected a shipbuilding project to be processed. The Application menu of Admin will be available menu such as project management, components identification, fabrication, assembly, erection, outfitting, launching, commissioning, sea trial, delivery, search, reject, reports, evaluations and recommendations menu. Admin can input data, view data, edit data, save data, print data, and delete data. Admin and User have the same menu page. The diference of both is permission to operate application.

In Figure 7., Users have approved by Admin, can access the application. Internal Shipyard can choose project, while external shipyard can not choose project. On the application menu, user will be available menu such as 
identification components, fabrication, assembly, erection, outfitting, launching, commissioning, sea trial, delivery, search, reject, reports, evaluations and recommendations. Users are given the permission to see data, print data, store data and make recommendations.

\section{1) Admin}

Simulation of Quality Management Applications for Admin is as follows,

a. Login

The login page is the earliest pages of the computer application program. By opening a browser and writing the address in the field address, Admin can input username and password on the login page of the application as shown in Figure 8.

\section{b. Menu}

After log in, Admin goes to the application home page. Admin choose project by clicking the View Project menu to determine what project will be processed as shown in Figure 9.

If project selected is not provided in the list of projects, so Admin click the Add Project menu, it will appear the add project page which contains of the ship's identity data which should be written by Admin. Admin has selected the project, will go into the Shibuilding process menu. The menu which is available in the application, is divided into two menu,they are main menu and additional menu. The main menu includes the stage of the components identification, fabrication, assembly, erection, outfitting, launching, commissioning, seatrial, and delivery. As well as additional menu includes menu of search, reject, report, evaluation and recommendation. In Figure 10., each of the Admin main menu has a sub menu like Input ITP, Add Data, View ITP and View Data. Figure 11. and Figure 12. are page display of input ITP and add data sub menu of fabrication menu. While Figure 13. and Figure 14. are page display of view ITP and View Data sub menu of fabrication menu.

As shown in Figure 11., Admin enters any check list to be examined by the Shipyard, Owner Surveyor, Class and State Regulators in the available space of Input ITP page. Each column is written by symbol O, R or (-). The symbol $\mathrm{O}$ means that the item is inspected by the parties concerned, the symbol $\mathrm{R}$ means that the item is random inspected by the parties concerned, the symbol (-) means that the item is not inspected by the parties concerned. As well as the Inspection standards which are used in the examination, are also written in the column.

Admin can enter Inspection data that have been done in the inspection form that is provided in the application. Application shows the Check lists like Figure 12. The application provides check list which are used as guidelines for inspection in the workshop.

As shown in Figure 13., Admin can see the result of input ITP on a sub menu view ITP. In this sub menu, Admin can see who parties are involved in an inspection. ITP can be changed by clicking the edit action.

As shown in Figure 14., Admin can view the detailed data, edit data and delete data by clicking the action which is available in the column of page.

In the additional menu, each menu has different function. Search menu is used to see data directly of inspection documents by typing the name of the component, outfitting, testing, documents or inspection date range in the column. Reject menu is used to allow all parties concerned to see the inspection documents with Reject status at every stage. Report menu is used to allow all parties concerned to see any items that have been checked by the Owner Surveyor, Class, and State Regulators. Evaluation menu is used to facilitate all parties concerned to see the inspection documents which had received and rejected by the Shipyard, Owner Surveyor, Class, and State Regulators at every stage. Recommendation menu is used to allow all parties concerned to provide comments and suggestions on the shipbuilding process.

In Figure 15., Admin look for data of main engine through search menu, then appeared the inspection documents of Main Engine at all stages.

\section{2) User}

Simulation of Quality management applications to users is as follows,

a. Login

On the login page, Users (QA, QC, Design, Procurement, Production, Owner Surveyor, State Regulators and Classification Society) enter username and password in available space to access the application. By clicking on the $\log$ in, it could enter into the application. Users who are not registered in the application, must previously register on the registration menu which put on the login page. There are two users, Internal Shipyard (QA, QC, Production, Design and Procurement Department) and External Shipyard (Owner Surveyor, Classification Society and State Regulators) as in Figure 16.

\section{b. Menu}

Application Menu of User is same as the Admin. But difference of them is permissions. The user can only see data, print data and download data. Sub-menus are available in the User, those are view ITP and view data. Users can not change, add, save, and delete data.

As shown in Figure 17., the display of sub menu view ITP in User. For this figure, Users viewed ITP for Fabrication menu.

As shown in Figure 18., the display of sub menu view Data Assembly for Users. Users can only see the details data and print the data. By clicking on detail view and by clicking on print data will appears as Figure 19.

In the search, reject, report, evaluation and recommendation menu, the user can only see and print the data. Functions of the additional menus on the User is same as in the Admin.

\section{ANALYSIS OF APPLICATION}

Quality management applications can assist the implementation of Inspection management on monitoring, searching, evaluating and doing the inspection. In conducting to review the inspection, the application system only takes 10 minutes, while the existing system is rarely even been commissioned to review the inspection. In the distribution of inspection documents, the application system only takes 7 minutes compared with existing system that takes 1 day. While in searching of inspection, the application system only takes 8 minutes and the existing system takes 3 hours. Existing systems can not directly control and evaluate the 
inspection, for the evaluation process is currently done only every three months. The application system has been designed with the control and evaluation systems directly to the inspection, so that the control and evaluation process can be run at any - time.

In Table 1., we can see the analysis of the weaknesses and strengths between existing system and application system that shows the difference of both. In Table 2., it can be concluded that the quality management application is good applied in the implementation of quality management process of shipbuilding.

\section{CONCLUSION}

The conclusions of research are as follows:

1) The quality management process in the shipyard has not been executed systematically. Inspection managements were not yet supported by the system that help the Shipyard, Owner Surveyor, Classification Society and State Regulators in controlling, searching, reviewing, evaluating and doing the inspections.
2) The application parameters are identified during the shipbuilding stages, process, ship components and ship documents, as well as the standards and check lists that sourced from ITP (Inspection Test Plan), Shipyard Quality Standard, IACS Shipbuilding Standard and Class rule.

3) Designing application is done through modelling applications, designing interface, designing database, and coding application stage. Software used to design is a combination of MySQL as database, PHP as programming language and Sublime Text 2 as text editor. Based on the comparison systems and verification testing, quality management application can control, search, review, evaluate, and do the inspection. Respondents (application user) asses the application is good enough to be used in quality management process in shipbuilding.

4) An interesting and innovative study to improve shipbuilding process.

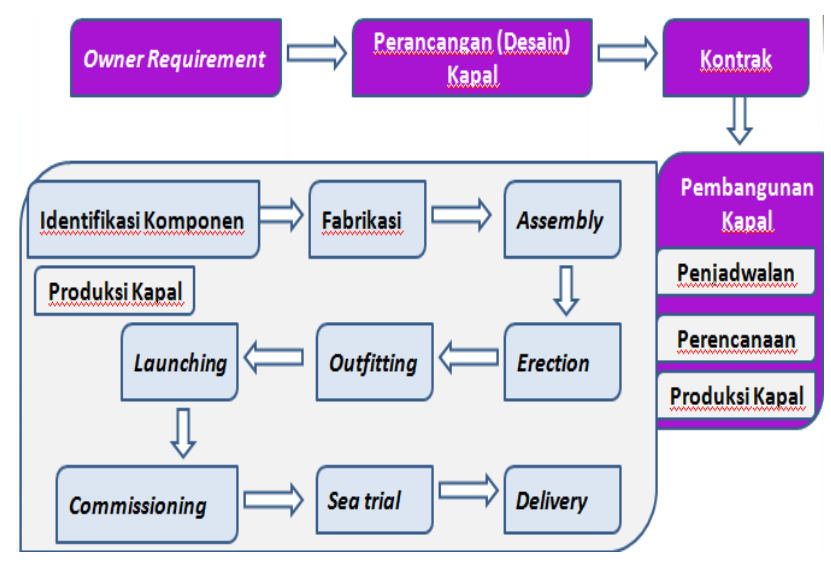

Figure. 1. Shipbuilding Process

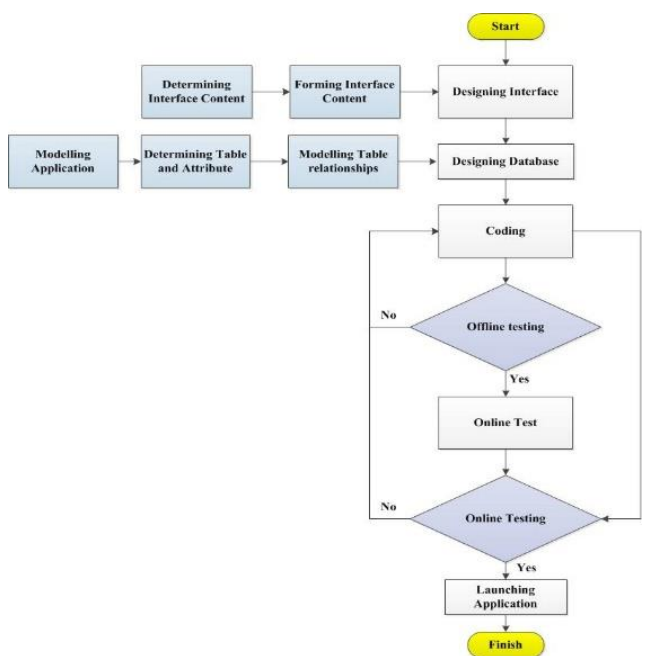

Figure. 2. Designing Application Proces

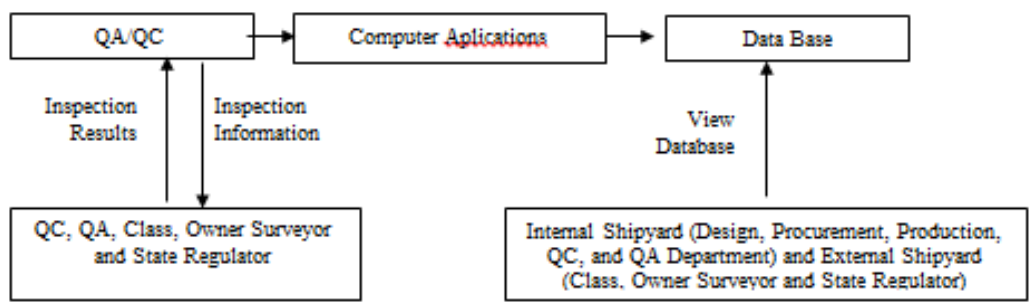

Figure 3. Framework Applications

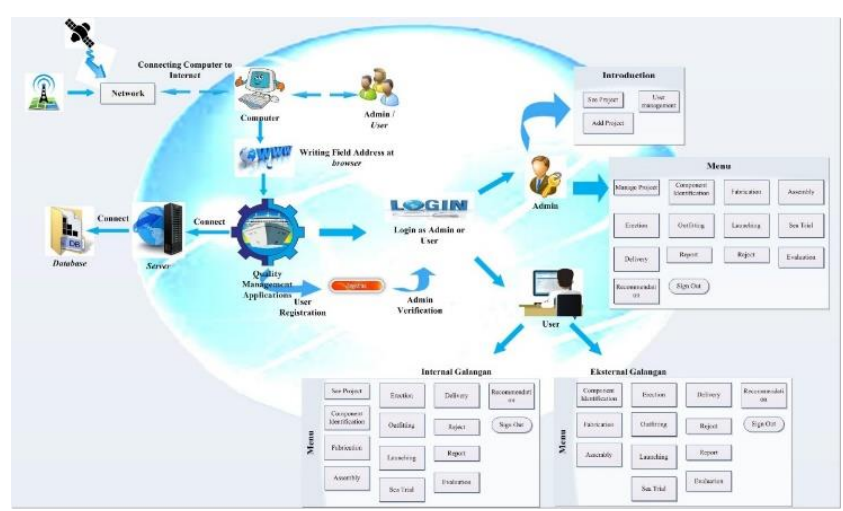

Figure 4. Mock Up Of Applications 
The $2^{\text {nd }}$ International Seminar on Science and Technology

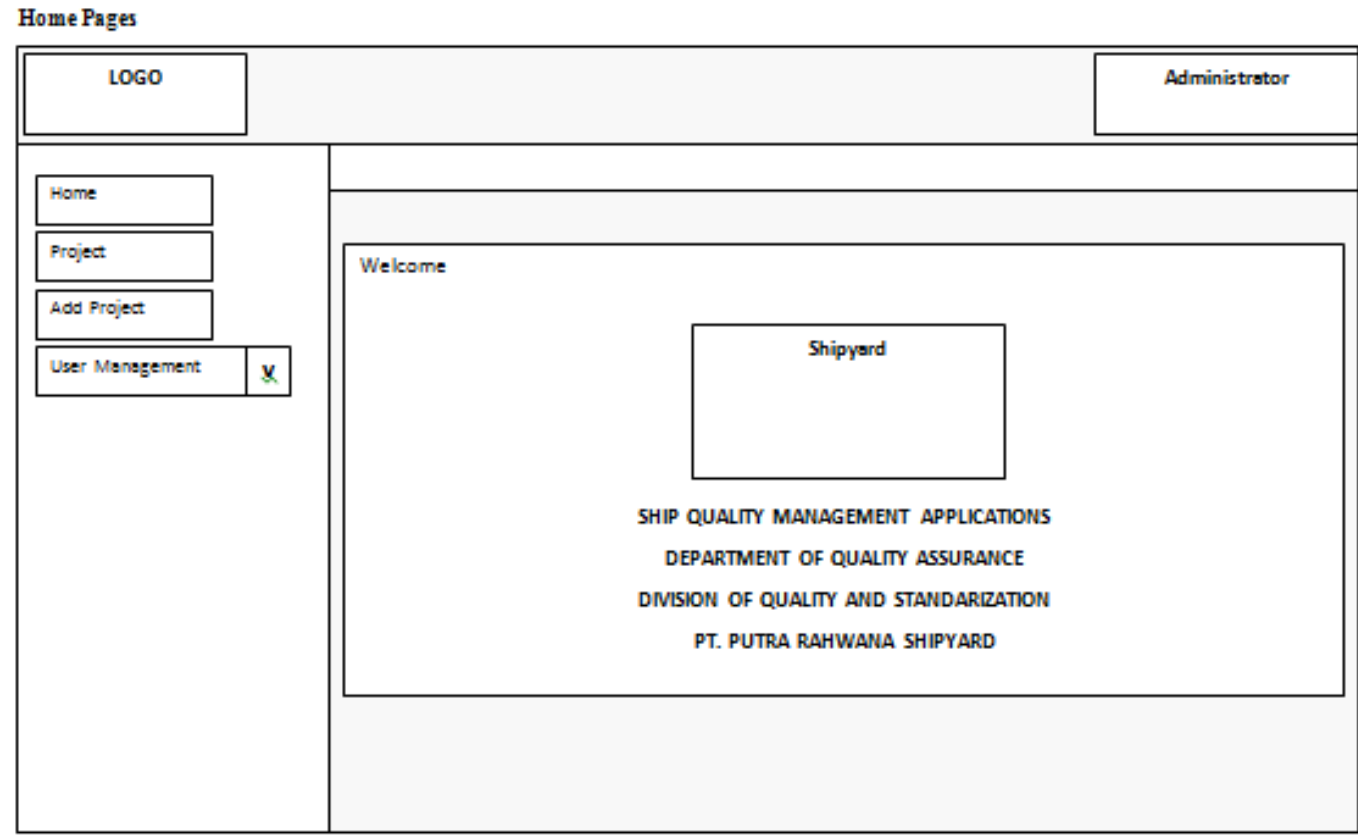

Figure 5. Applications Work Flow

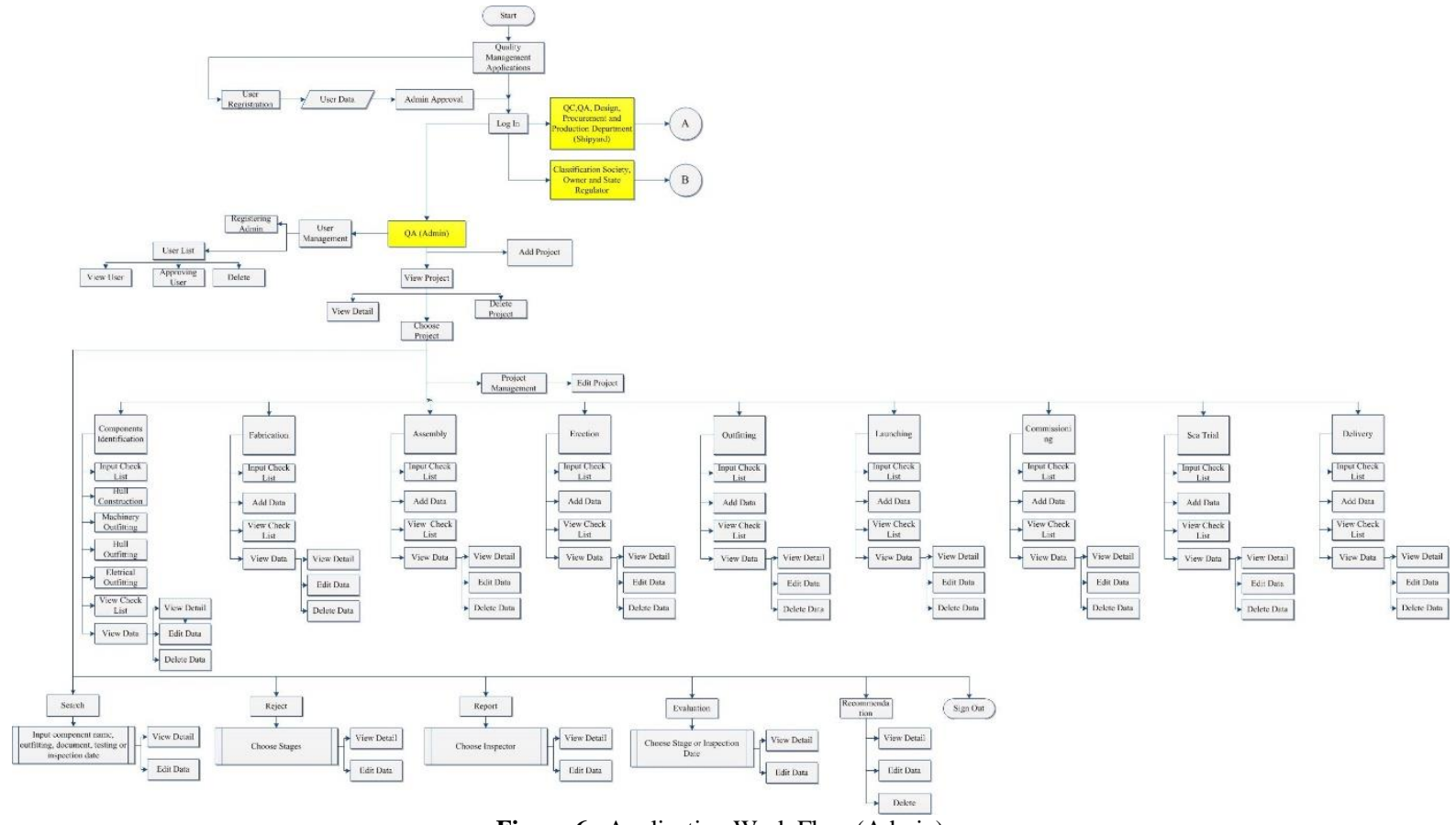

Figure 6. Application Work Flow (Admin)
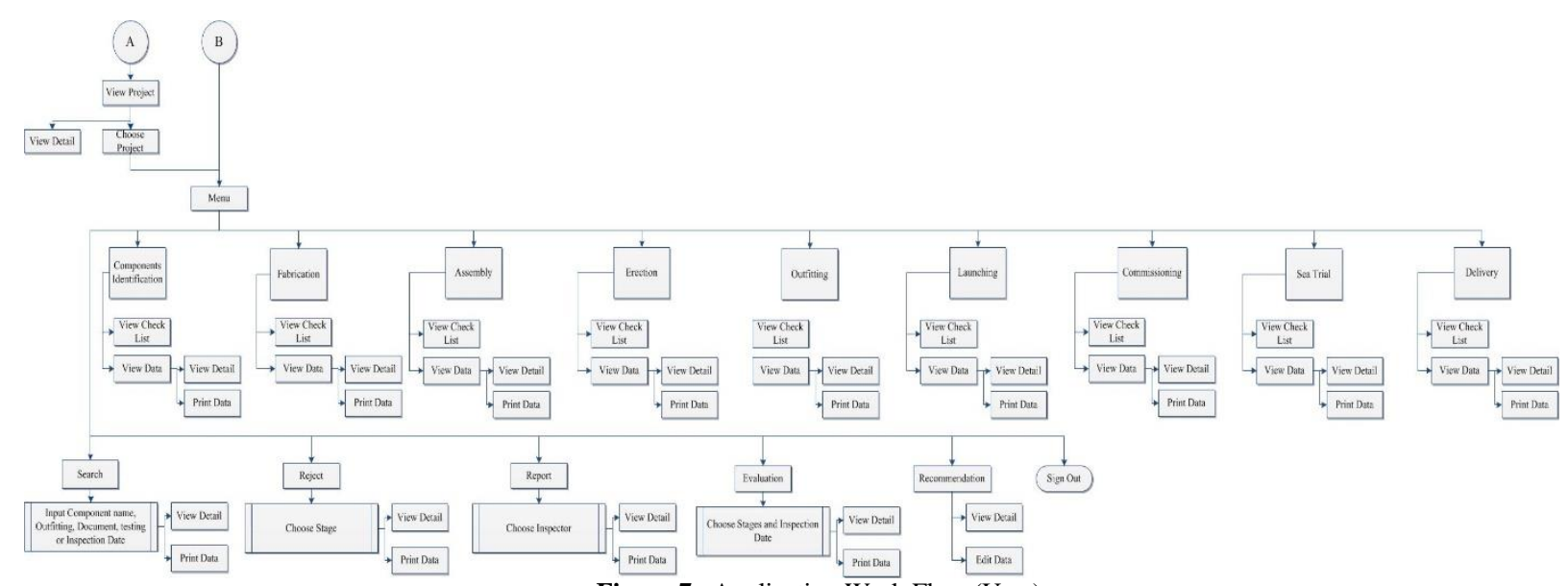

Figure 7. Application Work Flow (User) 


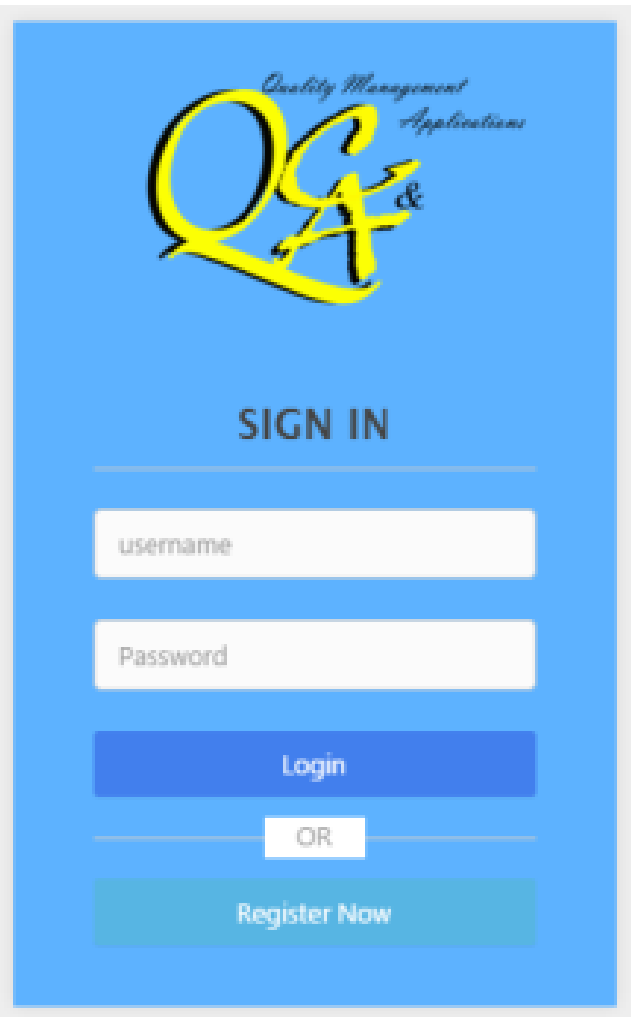

Figure 8. Login Page

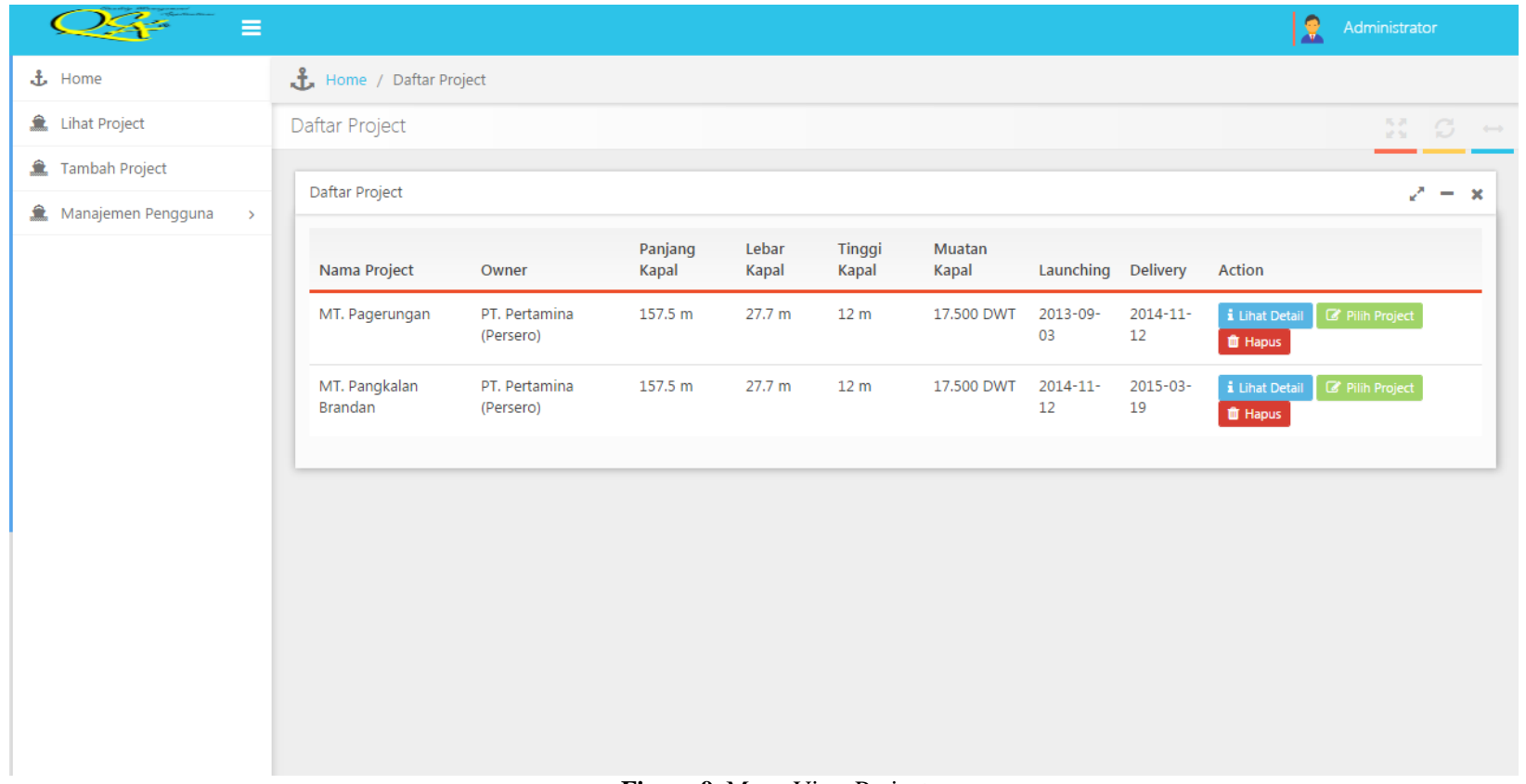

Figure 9. Menu View Project. 
The $2^{\text {nd }}$ International Seminar on Science and Technology

August $2^{\text {nd }}$ 2016, Postgraduate Program Institut Teknologi Sepuluh Nopember, Surabaya, Indonesia

\begin{tabular}{|c|c|c|}
\hline$\hat{\infty}$ & Kelola Project & $>$ \\
\hline 2 & Identifikasi Komponen & $>$ \\
\hline$\hat{\sin }$ & Fabrikasi & $\checkmark$ \\
\hline & Input ITP & \\
\hline & Tambah Data & \\
\hline & Lihat ITP & \\
\hline & Lihat List Data & \\
\hline 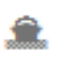 & Assembly & $>$ \\
\hline$\hat{2}$ & Erection & $>$ \\
\hline$\rightarrow$ & Outfitting & $>$ \\
\hline setse & Launching & $>$ \\
\hline s. & Commissioning & $>$ \\
\hline$\Leftrightarrow$ & Sea Trial & $>$ \\
\hline$\hat{x}$ & Delivery & $>$ \\
\hline$\Leftrightarrow$ & Search & \\
\hline
\end{tabular}

Figure 10. Menu and Sub Menu Application

\begin{tabular}{|c|c|c|c|c|c|c|}
\hline \multicolumn{6}{|l|}{ ITP Fabrikasi } & \multirow{2}{*}{$x^{x}-x$} \\
\hline \multicolumn{2}{|c|}{ Bagian Fabrikasi } & \multicolumn{2}{|c|}{ Hull Construction } & & & \\
\hline & Proses & Marking & $v$ & & & \\
\hline \multicolumn{7}{|c|}{ Silahkan lengkapi ITP di bawah ini } \\
\hline sudut penjuru dibanding & Galangan & & Owner Surveyor & Class & State Regulator & Standard \\
\hline Sudut penjuru dibanding & Galangan & & Owner Surveyor & Class & State Regulator & Standard \\
\hline Lengkungan & Galangan & & Owner Surveyor & Class & State Regulator & Standard \\
\hline Penempatan komponen & Galangan & & Owner Surveyor & Class & State Regulator & Standard \\
\hline $\begin{array}{l}\text { Penandaan block } \\
\text { dibanding yang }\end{array}$ & Galangan & & Owner Surveyor & Class & State Regulator & Standard \\
\hline $\begin{array}{l}\text { Penempatan komponen } \\
\text { untuk pemasangan pada }\end{array}$ & Galangan & & Owner Surveyor & Class & State Regulator & Standard \\
\hline
\end{tabular}

Figure 11. Page of Input ITP Fabrication 


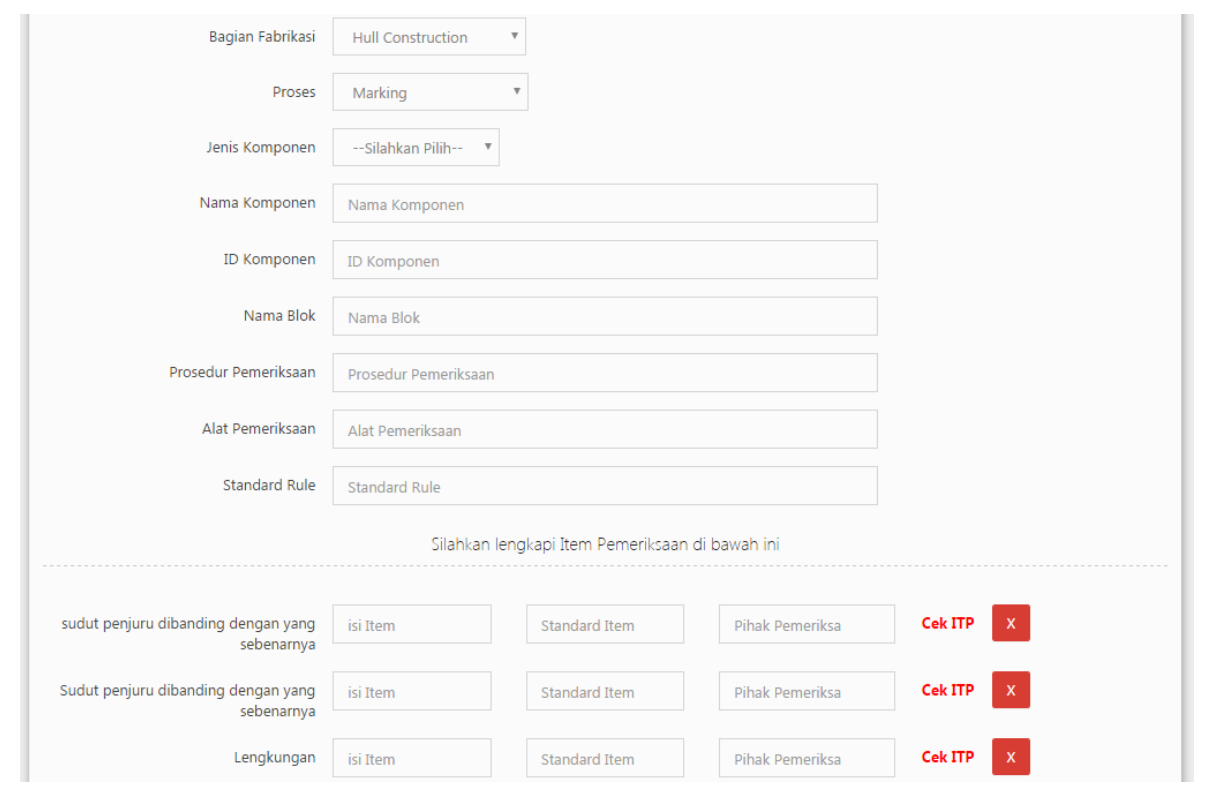

Figure 12. Page of Add Data Fabrication

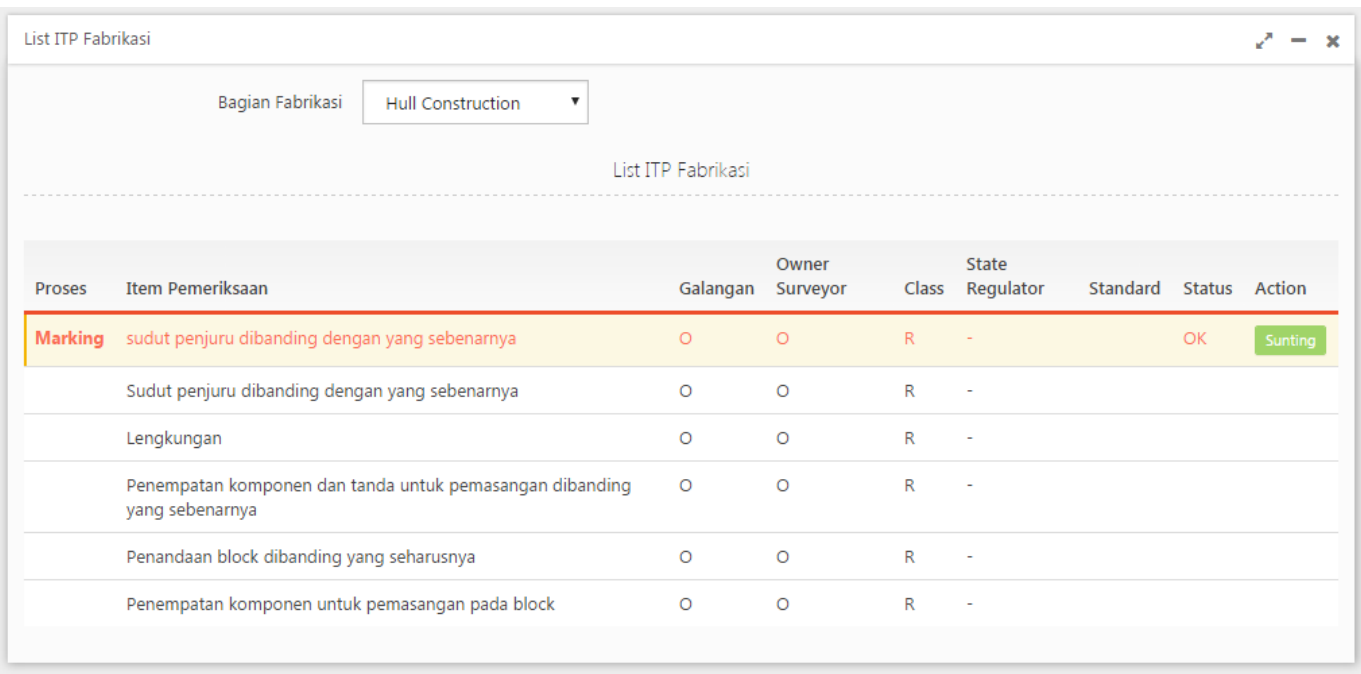

Figure 13. Page of View ITP Fabrication

\begin{tabular}{|c|c|c|c|c|c|c|c|c|c|c|}
\hline \multicolumn{7}{|c|}{ Daftar Project } & & & & $x^{x}-x$ \\
\hline & Pilih Bagian & Hull Cor & struction & $\checkmark$ & & & & & & \\
\hline \multicolumn{11}{|c|}{ List Fabrikasi } \\
\hline No & Nama & ID & $\mathrm{QC}$ & QA & Class & Owner & State & & & \\
\hline ID & Komponen & Komponen & Inspector & Coordinator & Surveyor & Surveyor & Regulator & Status & Action & \\
\hline \multirow[t]{2}{*}{5} & U 1110173 & & Panuju & Karmuji & Lukito & Bambang $\mathrm{HP}$ & & OK & i Lihat Detail & $\mathbb{Z}$ Sunting Data \\
\hline & & & Riyono & & & & & & tu Hapus & \\
\hline \multirow[t]{2}{*}{6} & U 2105325 & & Irwan & Karmuji & Sudarsono & Prima & & OK & i Lihat Detail & $\mathbb{Z}$ Sunting Data \\
\hline & & & Prasetyo & & & & & & to Hapus & \\
\hline \multirow[t]{2}{*}{7} & U 2105298 & & Didik K & Karmuji & Lukito & Bambang $\mathrm{HP}$ & & OK & i Lihat Detail & $\mathbb{Z}$ Sunting Data \\
\hline & & & & & & & & & to Hapus & \\
\hline
\end{tabular}

Figure 14. Page of View Data Fabrication 


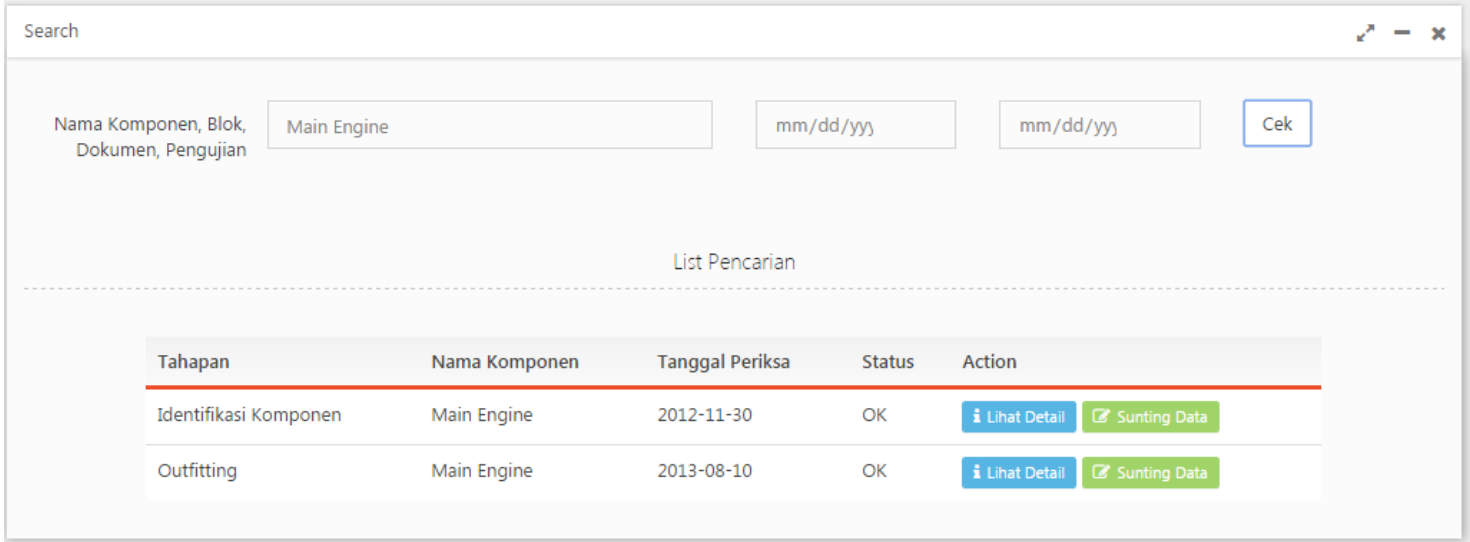

Figure 15. Page of Search Menu

\section{REFERENCES}

[1] PT. PAL Indonesia,"Business Process of Quality Assurance and Standardization Division,"Surabaya : PT. PAL Indonesia, 2015.

[2] Prihantoro, C. Rudy, "The Concept of Quality Control," Bandung : PT. Remaja Rosdakarya, 2012, pp. 3-10.

[3] Wahyuddin, "Ship Production Technology," Makassar : Naval Architecture Department, Hasanudin University, 2011, pp. 9-13.

[4] PT. PAL Indonesia, "PAL Shipbuilding Quality Standard," Surabaya : PT. PAL Indonesia, 2012.
[5] IACS, "Shipbuilding and Repair Quality Standards for New Construction," IACS, (Rec.1996).

[6] Yakub, "Introduction of Information Systems," Yogyakarta : Graha Ilmu, 2012

[7] Kusuma, YM Ardhana, "PHP \& MySQL Project : Creating a Digital Book Website,” Purwokerto : Jasakom, 2014, pp. 4570.

[8] Al Fatta, Hanif, “Analysis and Design Information Systems for the Competitive Advantage of Companies and Modern Organizations," Yogyakarta : Andi offset, 2007. 